\title{
Key structural and functional differences between early and advanced glycation products
}

\author{
Beatriz Paradela-Dobarro', Bruno K Rodiño-Janeiro ${ }^{1,+}$, Jana Alonso ${ }^{2, \pm}$, \\ Sergio Raposeiras-Roubín ${ }^{3}$, Mercedes González-Peteiro ${ }^{4}$, \\ José R González-Juanatey ${ }^{1,3}$ and Ezequiel Álvarez ${ }^{1}$ \\ ${ }^{1}$ Laboratorio no 6. Grupo de Cardiología, Instituto de Investigación Sanitaria de Santiago (IDIS), \\ Santiago de Compostela, Spain \\ ${ }^{2}$ Servicio de proteómica. Instituto de Investigación Sanitaria de Santiago (IDIS), Santiago de Compostela, Spain \\ ${ }^{3}$ Servicio de Cardiología, Complejo Hospitalario Universitario de Santiago de Compostela, \\ Santiago de Compostela, Spain \\ ${ }^{4}$ Departamento de Enfermería, Universidad de Santiago de Compostela, Santiago de Compostela 15782, Spain \\ ${ }^{\dagger} \mathrm{B} K$ Rodiño-Janeiro is now at Hospital Vall d'Hebron, Barcelona, Spain \\ ${ }^{\ddagger} \mathrm{J}$ Alonso is now at MRC Protein Phosphorylation and Ubiquitylation Unit, Dundee, Scotland, UK
}

Correspondence should be addressed to E Álvarez Email ezequiel.alvarez.castro@ gmail.com

\begin{abstract}
Most of the studies on advanced glycation end products (AGE) have been carried out with uncharacterized mixtures of $A G E$, so the observed effects cannot be linked to defined structures. Therefore, we analysed the structural differences between glycated human serum albumin (gHSA), a low glycated protein, and AGE-human serum albumin (AGE-HSA), a high glycated protein, and we compared their effects on endothelial functionality. Specifically, we characterized glycation and composition on both early and advanced stage glycation products of gHSA and AGE-HSA by using the MALDI-TOF-mass spectrometry assay.

Furthermore, we studied the effects of both types of glycation products on reactive oxygen species (ROS) production and in the expression of vascular and intercellular cell adhesion molecules (VCAM-1 and ICAM-1) on human umbilical endothelial cells (HUVEC). We also measured the adhesion of peripheral blood mononuclear cells (PBMC) to HUVEC. Low concentrations of gHSA enhanced long-lasting ROS production in HUVEC, whereas lower concentrations of AGE-HSA caused the anticipation of the induced extracellular ROS production. Both gHSA and AGE-HSA up-regulated the expression of VCAM-1 and ICAM-1 at mRNA levels. Nevertheless, only AGE-HSA increased protein levels and enhanced the adhesion of PBMC to HUVEC monolayers. Functional differences were observed between gHSA and AGE-HSA, causing the latter an anticipation of the pro-oxidant effects in comparison to gHSA. Moreover, although both molecules induced genetic up-regulation of adhesion molecules in HUVEC, only the high glycated protein functionally increased mononuclear cell adhesion to endothelial monolayers. These observations could have important clinical consequences in the development of diabetic vascular complications.
\end{abstract}

Journal of Molecular Endocrinology (2016) 56, 23-37
Key Words

- glycated human serum albumin

- advanced glycation end products

- human endothelial cells functionality

- vascular adhesion molecules

- peripheral blood mononuclear cells adhesion 


\section{Introduction}

Aging-associated diseases such as cardiovascular disease, neurodegenerative disorders and other chronic conditions play important roles in restraining the quality of life of the aging population (Rahman 2007, Ott et al. 2014). A lot of chronic diseases are associated with the accumulation of age-related modified biomolecules. In the context of cardiovascular diseases, the accumulation of damaged biomolecules is responsible for the atherosclerotic plaque formation and contributes to the endothelial dysfunction (Negre-Salvayre et al. 2008, Ott et al. 2014).

One of the best-characterized groups of modified biomolecules is the advanced glycation end products (AGE). This heterogeneous group results from nonenzymatic glycation and oxidation of proteins, nucleic acids and lipids (Thorpe \& Baynes 2003, Luevano-Contreras \& Chapman-Novakofski 2010). The glycation process, first described by Maillard (1912), begins with the reaction between carbonyl groups of reducing sugars, like glucose, with free amine groups of proteins, lipids and nucleic acids to form a reversible Schiff base. These compounds can later undergo rearrangements to form Amadori products, which are more stable but still reversible (Bucala et al. 1993). Thus, early glycation and oxidation processes result in the formation of Schiff bases and Amadori products, considered to be the early stage glycation products (ESGP). Further chemical rearrangement and cleavage of these compounds can lead to irreversible modifications resulting in the formation of advanced stage glycation products (ASGP) (Thorpe \& Baynes 2003, Zieman \& Kass 2004).

ASGP and ESGP are naturally formed inside the body along with the aging process but its formation is accelerated in hyperglycemia, oxidative stress and conditions in which protein and lipid turnover is prolonged (Prasad 2014). AGE accumulation is involved in the development of chronic diseases as vascular complications of diabetes and in the development of inflammation in atherosclerosis as well (Zhang et al. 2009). Moreover, this accumulation plays a pathological role in the development of atherosclerosis by cross-linking collagen in vessel walls, producing stiffness of blood vessels, oxidizing low density lipoprotein and increasing inflammation through the receptor for AGE (RAGE) (Sims et al. 1996, Zieman \& Kass 2004). During AGE-mediated inflammatory responses, endothelial cells undergo a process of activation, characterized by enhanced cellular permeability and the up-regulation of leukocyte adhesion molecules (Funk et al. 2012).
There are several studies focused on the cellular effects of AGE. However, the AGE-proteins usually used as a stimulus in the vast majority of these studies are the result of the incubation of a given protein with a glycating agent. As a result, an uncharacterized mixture of different AGE structures is obtained, and the observed physiological effect cannot be related to any defined structures (Kislinger et al. 2005). In this situation, when the molecular cause of the observed effect is unknown, the relevance of this physiological effect in vivo is not clear. It is not even clear if the reported effects of AGE are caused only or in its majority by these specific modifications or if they could be produced more specifically by ESGP or by a combination of ESGP and ASGP.

For this reason, exploring the differential effects of low glycated and high glycated proteins, with different composition on ESGP and ASGP in a human cellular model was our major objective. To do that, we first characterized one commercial and one homemade glycated protein as a model of both types of compounds by using matrix-assisted laser desorption/ionization time-of-flight mass spectrometry (MALDI-TOF-MS), thus, providing a detailed overview of the total protein modifications present in those molecules. We analysed the structural differences between ESGP and ASGP by using glycated human serum albumin (gHSA) and AGE-human serum albumin (AGE-HSA) as models of low and high glycated compounds respectively. Following this, we investigated the differential effect of these specific molecules on the endothelial dysfunction process. To do that, we studied the effect of these structures in the reactive oxygen species (ROS) production and in the expression of adhesion molecules on our model of human umbilical endothelial cells (HUVEC).

\section{Materials and methods}

\section{Glycation level determination by MALDI-TOF-MS analysis}

AGE-HSA was prepared in vitro under sterile conditions by incubating $50 \mathrm{mg} / \mathrm{ml}$ of HSA in PBS with $500 \mathrm{mmol} / \mathrm{l}$ of glucose at $37^{\circ} \mathrm{C}$ for 4 weeks. The product of this incubation was dialyzed against PBS to remove free sugars and stored at $-20^{\circ} \mathrm{C}$ until use. AGE-HSA from this stock solution was diluted daily in PBS to the concentration needed for each experiment. Control nonglycated HSA (ct-HSA) was treated identically to AGE-HSA (i.e., incubation at $37^{\circ} \mathrm{C}$ for 4 weeks and dialysis) except that no glucose was present in the reaction mixture.

Published by Bioscientifica Ltd. 
We followed up the glycation stage in HSA by MALDITOF-MS. For this purpose, HSA and gHSA (commercially available) and AGE-HSA (produced in the laboratory following the procedure described above) were submitted to MALDI-TOF-MS to corroborate the molecular weight increment due to the incorporation of different glycation products to the HSA. Stock samples at $4 \mathrm{mg} / \mathrm{ml}$ were diluted in a solution of $8 \mathrm{mg} / \mathrm{ml}$ of $\alpha$-cyano-4-hydroxycinnamic acid (CHCA) in $80 \%$ acetonitrile (ACN) and $0.3 \%$ trifluoroacetic acid (TFA) at different protein ratios $(1: 5,1: 25,1: 50)$, obtaining 1:25 for the best resolution, signal to noise and peak intensity. From this mix, $0.5 \mu \mathrm{l}$ was spotted onto a 384 Opti-TOF MALDI plate (Applied Biosystems). Mass spectrometric analysis was performed in a 4800 MALDI-TOF/TOF analyser (Applied Biosystems). MS spectra were acquired in linear mode with a neodymium-doped yttrium aluminium garnet (Nd:YAG), $355 \mathrm{~nm}$ wavelength laser, averaging 500 laser shots. All of the spectra were externally calibrated with three peaks of HSA in adjacent spots (monocharged $66478 \mathrm{Da}$, dicharged $33239 \mathrm{Da}$ and tricharged $22159 \mathrm{Da}$ ). Six independent MS analyses were performed for each sample, and the mean molecular weight for each species was calculated (Supplementary Table S1, see section on supplementary data given at the end of this article).

\section{Quantification of free amino groups quantification}

Free amino groups in glycated proteins were estimated using TNBSA (2,4,6-trinitrobenzene sulfonic acid; Thermo Fisher Scientific, Waltham, MA, USA) following the manufacturer's instructions. Briefly, $15 \mu \mathrm{g}$ of each protein were mixed/ diluted in $250 \mu \mathrm{l}$ of $0.1 \mathrm{M} \mathrm{NaHCO}_{3}(\mathrm{pH} 8.5$ ) and $125 \mu \mathrm{l}$ of $0.01 \%(\mathrm{w} / \mathrm{v})$ solution of TNBSA in $0.1 \mathrm{M}$ $\mathrm{NaHCO}_{3}$. The mixtures were incubated at $37^{\circ} \mathrm{C}$ for $2 \mathrm{~h}$ after which the absorbance at $335 \mathrm{~nm}$ was measured. Quantitative determination was made in comparison to a standard curve of known concentrations of lysine $(0.3-10 \mu \mathrm{g} / \mathrm{ml})$ in $0.1 \mathrm{M} \mathrm{NaHCO}_{3}$.

\section{ESGP and ASGP determination by MALDI-TOF-MS analysis}

HSA, gHSA and AGE-HSA were run in sodium dodecyl sulphate-12\% polyacrylamide gel electrophoresis (SDSPAGE). After that, several spots from the bands were 'picked out' using a cutting keratin-free pipet tip. The excised protein features were manually digested. The gel pieces were rinsed three times with AmBic buffer consisting of $50 \mathrm{mM}$ ammonium bicarbonate in 50\% methanol (HPLC grade, Scharlau, Barcelona, Spain) following a reduction step with $10 \mathrm{mM}$ dithiothreitol in $50 \mathrm{mM}$ ammonium bicarbonate (Sigma-Aldrich). Hereunder, the gel pieces were rinsed twice with AmBic buffer and dried in a SpeedVac (Thermo Fisher Scientific, Waltham, MA, USA) before alkylation with $55 \mathrm{mM}$ iodoacetamide (SigmaAldrich) in $50 \mathrm{mM}$ ammonium bicarbonate. Once again, the gel pieces were rinsed with AmBic buffer (HPLC grade) before being dehydrated by the addition of acetonitrile (HPLC grade, Scharlau) and dried in a SpeedVac (Thermo Fisher Scientific). Modified porcine trypsin (Promega) was added to the dry gel pieces at a final concentration of $20 \mathrm{ng} / \mu \mathrm{l}$ in $20 \mathrm{mM}$ ammonium bicarbonate, incubating them at $37^{\circ} \mathrm{C}$ for $16 \mathrm{~h}$. Peptides were extracted three times by $20 \mathrm{~min}$ incubation in $40 \mu \mathrm{l}$ of $60 \%$ acetonitrile in $0.5 \% \mathrm{HCOOH}$. The resulting peptide extracts were pooled, concentrated in a SpeedVac and stored at $-20^{\circ} \mathrm{C}$. Dried samples were dissolved in $3 \mu \mathrm{l}$ of $0.5 \% \mathrm{HCOOH}$. Equal volumes $(0.5 \mu \mathrm{l})$ of peptide and matrix solution, which consisted of $3 \mathrm{mg}$ CHCA dissolved in $1 \mathrm{ml}$ of $50 \%$ acetonitrile in $0.1 \%$ TFA, were deposited using the thin layer method onto a 384 Opti-TOF MALDI plate (Applied Biosystems). Mass spectrometric data were obtained in an automated analysis loop using a 4800 MALDI-TOF/TOF analyzer (Applied Biosystems). Mass spectra (MS) were acquired in reflectron positive-ion mode with a Nd:YAG, $355 \mathrm{~nm}$ wavelength laser, averaging 1000 laser shots, and at least three trypsin autolysis peaks were used as internal calibration. All tandem mass spectometry (MS/MS) were performed by selecting the precursors with a relative resolution of 300 (full width at half maximum, FWHM) and metastable suppression. Automated analysis of mass data was achieved using the 4000 Series Explorer Software V3.5 (Applied Biosystems/MDS SCIEX, Foster City, CA, USA). MS and MSMS data were combined through the GPS Explorer Software v3.6 (Applied Biosystems/MDS SCIEX) using Mascot Software v2.1 (Matrix Science Ltd, London, UK) to search against a non-redundant database (SwissProt 20100326), with $30 \mathrm{ppm}$ precursor tolerance and $0.35 \mathrm{Da} \mathrm{MS} / \mathrm{MS}$ fragment tolerance and allowing one missed cleavage. All spectra and database results were manually inspected in detail using the previous software.

Glycation-modified peptides were manually explored by the addition of the different glycostructures defined in Supplementary Table S2, see section on supplementary data given at the end of this article. Due to the fact that MALDI-TOF error tolerance is in the second decimal, we can undoubtedly assign which glycation modifications are carried out on gHSA or on AGE-HSA. Only pentosidine (with a $\Delta \mathrm{Da}+58.03$ ) and CML (with a $\Delta \mathrm{Da}+58.02$ ) that differ by $0.01 \mathrm{Da}$ cannot be distinguished.

Published by Bioscientifica Ltd. 


\section{Cell culture and cell viability's experiments}

HUVEC were isolated from freshly obtained human umbilical cords donated under informed consent from mothers, following the method previously described (Rodino-Janeiro et al. 2010). All procedures were approved by the Ethics Committee for Clinical Research at Galicia (Spain), according to the World Medical Association Declaration of Helsinki. HUVEC were cultured on $0.2 \%$ $(\mathrm{w} / \mathrm{v})$ gelatin (Sigma-Aldrich) pre-coated flasks or dishes (Corning, New York, NY, USA) and grown in complete endothelial growth medium (EGM)-2 (Lonza, Basle, Switzerland) in a humidity-saturated atmosphere with $5 \% \mathrm{CO}_{2}$ at $37^{\circ} \mathrm{C}$. Before each experiment, cells were serum starved in endothelial basal medium (EBM)-2 (Lonza). Cells for the experiments were used between the second and seventh passage. For the treatments, HSA was used as a control for gHSA and ct-HSA for AGE-HSA, as defined earlier.

The real-time cell analyser (RTCA SP Instrument; Roche Applied Science) is an impedance-based technology that was used for label-free and real-time monitoring of the cell viability of HUVEC under different conditions (Fandino-Vaquero et al. 2014). Viability and growth of HUVEC in the presence of HSA, ct-HSA, gHSA or AGE-HSA at different concentrations $(12-400 \mu \mathrm{g} / \mathrm{ml})$ in EBM-2 medium were registered continuously during $12 \mathrm{~h}$. The system monitored cellular events in real time measuring electrical impedance across interdigitated micro-electrodes integrated on the bottom of cell culture E-plates. These measurements, called Cell Index (CI) dynamic values, were monitored at 10-min intervals from the time of plating until the end of the experiment $(20 \mathrm{~h})$. All registers of CI were normalized to 1.000 arbitrary units (a.u.) at the time of the treatment and CI values after $12 \mathrm{~h}$ of treatment were calculated. Each registry was made in duplicate.

\section{Measurement of reactive oxygen species in HUVEC}

For these experiments, 10000 cells were plated in a 96-wells plate, serum-starved for $12 \mathrm{~h}$ and treated with the different glycated products, as indicated above. Extracellular ROS production of HUVEC was measured by the cytochrome $\mathrm{C}$ reduction method, as previously described (Rodino-Janeiro et al. 2010). Briefly, after treatments, the HUVEC were incubated in HEPES buffer solution (HBS) supplemented with $1.5 \mathrm{mM} \mathrm{CaCl}_{2}$ (calcium-rich HBS) containing $200 \mu \mathrm{M}$ cytochrome C. Superoxide production was induced by adding reduced $\beta$-nicotinamide adenine dinucleotide (NADH, $100 \mu \mathrm{M}$ ) to the wells. The specificity of the measured superoxide anion was confirmed by inhibition with superoxide dismutase (SOD) $(100 \mathrm{U} / \mathrm{ml})$, a specific enzyme scavenger for these anions. Cytochrome $\mathrm{C}$ reduction was observed by reading the absorbance at $550 \mathrm{~nm}$ on a microplate reader (Multiscan Ex, Thermo-labsystems, Helsinki, Finland) for $100 \mathrm{~min}$ at $37^{\circ} \mathrm{C}$ to obtain the $\Delta \mathrm{Abs}_{550 \mathrm{~nm}} / \mathrm{min}$ for each experiment. The increase in ROS production from HUVEC treated with several concentrations of gHSA vs HSA or AGE-HSA vs ct-HSA was compared. To do that, we calculated the ratio of the rates of cytochrome $\mathrm{C}$ reduction $\left(\Delta \mathrm{Abs}_{550 \mathrm{~nm}} / \mathrm{min}\right)$ from both treatments (gHSA/HSA or AGE-HSA/ct-HSA).

Intracellular ROS production of HUVEC was measured by 5(6)-carboxy-2',7'-dichlorofluorescein diacetate (cDCF-DA; Sigma-Aldrich), as previously described (Rodino-Janeiro et al. 2010). Briefly, after treatments, HUVEC were incubated at $37^{\circ} \mathrm{C}$ in the dark with EBM-2 medium containing $5 \mu \mathrm{M}$ cDCF-DA for $15 \mathrm{~min}$. After incubation, cells were washed to eliminate the cDCF-DA not incorporated into the cells and fresh media was added. Intracellular ROS production was then measured in a fluorescence microplate reader (Fluostar Optima, BMG LABTECH, GmbH, Ortenberg, Germany) at 485:520 nm (excitation:emission) for $30 \mathrm{~min}$. Each assay was carried out with six replicates.

\section{mRNA isolation and real-time PCR determination}

After the treatments, the cell culture medium was aspirated; cells were washed three times with pre-cooled PBS and lysed in RP1 lysis buffer (Macherey-Nagel, Düren, Germany). Total cellular RNA from HUVEC was extracted using a NucleoSpin kit (Macherey-Nagel) according to the manufacturer's protocol and quantified using a spectrophotometer (Nanodrop ND-1000, Thermo Fischer Scientific). Of the isolated total RNA, $1 \mu \mathrm{g}$ was reverse transcribed in a total volume of $20 \mu \mathrm{l}$ with the Maxima First Strand cDNA Synthesis Kit for RT-qPCR (Fermentas, Thermo Fisher Scientific), according to the manufacturer's instructions. cDNA $(2 \mu \mathrm{l})$ was used for quantitative real-time PCR using FastStart SYBR Green Master Mix (Hoffmann-La Roche) with a real-time detection thermal cycler system (Stratagene MX-3005P, Agilent Technologies, Santa Clara, CA, USA) in a 96-well plate according to the manufacturer's instructions. PCR conditions were $95^{\circ} \mathrm{C}$ for $10 \mathrm{~min}$, followed by 40 cycles of $95^{\circ} \mathrm{C}$ for $30 \mathrm{~s}, 63^{\circ} \mathrm{C}$ for $60 \mathrm{~s}$ and $72{ }^{\circ} \mathrm{C}$ for $60 \mathrm{~s}$. The relative expression ratio was calculated by the comparative threshold method using $\beta$-actin as housekeeping gene from the following equation: $R=2^{-[\Delta \text { Ctsample- }-\Delta \text { Ctcontrol }]}$, where $\mathrm{Ct}$ is the cycle threshold value. Amplification

Published by Bioscientifica Ltd 
efficiencies for the genes under study were calculated from raw data collected during the exponential phase. It was confirmed that these efficiencies were equal. The specific primers used were 5'-TTCTGACCCATGCCCACCAT-3' (sense) and 5'-ATGGATGATGATATCGCCGCGCTC-3' (antisense) for $\beta$-actin (NM_001101.2), 5'- TCCGTCTCATTGACTTGCAG-3' (sense) and 5'-CACCTGGATTCCTTTTTCCA-3' (antisense) for vascular cell adhesion molecule-1 (VCAM-1; M30257) and 5'-GAGATCACCATGGAGCCAAT-3' (sense) and 5'-ACTGTGGGGTTCAACCTCTG-3' (antisense) for intercellular cell adhesion molecule-1 (ICAM-1; NM_000201). The quality of the quantitative PCR (qPCR) products was checked at the end of each PCR by a dissociation curve from 60 to $95^{\circ} \mathrm{C}$ from which the melting temperatures of each product was calculated. These melting temperatures were related to the expected number of base pairs (bp) for each PCR product assessed by electrophoresis in agarose gels during the standardization of the qPCR conditions.

\section{Whole cell extracts and western blot analysis}

After treatments, total protein from HUVEC was extracted using the NucleoSpin kit (Macherey-Nagel) according to the manufacturer's protocol and directly solved and reduced on the protein solving buffer supplied. Total proteins were resolved by electrophoresis on $8 \%$ SDSpolyacrylamide gels followed by transfer to nitrocellulose membranes (Bio-Rad Laboratories). Membranes were subsequently blocked with $5 \%$ non-fat milk diluted in Tris-buffered saline with $0.1 \%$ Tween 20 (TBS-T) and incubated overnight at $4{ }^{\circ} \mathrm{C}$ with appropriate antibodies (Santa Cruz Biotechnology) diluted in TBS-T 5\% BSA: antiVCAM-1 (1/1000 dilution), anti-ICAM-1 (1/500) and anti$\beta$-actin (1/5000) for loading control. Secondary antibodies, anti-mouse (1/1000 for ICAM- 1 and $1 / 10000$ for $\beta$-actin) and anti-goat (1/2000 for VCAM-1), were purchased from Thermo Fisher Scientific, Inc. After washing, the protein bands were detected using chemiluminescence substrate (Pierce, Rockford, IL, USA) according to the manufacturer's recommendations.

\section{Peripheral blood mononuclear cells isolation and staining}

Human buffy coats from healthy donors were kindly provided by Centro de Transfusiones de Galicia (Santiago de Compostela, Spain). Peripheral blood mononuclear cells (PBMC) were isolated by density gradient centrifugation using Histopaque 1077 (Sigma-Aldrich), following the manufacturer's instructions. Briefly, $5 \mathrm{ml}$ of buffy coat were diluted in $15 \mathrm{ml}$ PBS with 5\% FBS, well mixed and carefully layered onto Histopaque 1077. Then, it was centrifuged at $400 \times \boldsymbol{g}$ for $30 \mathrm{~min}$ at room temperature with no break. After centrifugation, the upper layer was aspirated with a Pasteur pipette and the opaque interface transferred into a clean tube. The cells were washed twice using PBS with 5\% FBS to avoid cells clumping. Following this, cells were centrifuged at $200 \times \boldsymbol{g}$ for $15 \mathrm{~min}$ for removal of most of the platelets. The cell pellet was resuspended in PBS with 5\% FBS at a final concentration of $5 \times 10^{6}$ cells $/ \mathrm{ml}$ and labelled with Calcein AM (Invitrogen, Thermo Fischer Scientific) for $30 \mathrm{~min}$. Then cells were rinsed twice to remove unlabelled Calcein $\mathrm{AM}$ and kept at $37^{\circ} \mathrm{C}$ and $5 \% \mathrm{CO}_{2}$ in the incubator until use.

\section{Adhesion assay}

To measure adherence of the PBMC to endothelial cells, HUVEC were seeded into 96-well plates (Corning), precoated with gelatine $2 \%(\mathrm{w} / \mathrm{v})$ and incubated at $37^{\circ} \mathrm{C}$. At confluence, cells were serum-starved in EBM (Lonza) without any supplement for 3-4 h - enough time to stop the growing of the cells without affecting the monolayer (data not shown) - and then incubated with different treatments for $4 \mathrm{~h}$. Tumour necrosis factor- $\alpha$ (TNF- $\alpha)$ at a final concentration of $10 \mathrm{ng} / \mathrm{ml}$ was used as positive control of the assay. After incubation, $2 \times 10^{5} \mathrm{PBMC} /$ well were layered over the endothelial cells. The plate was incubated at $37^{\circ} \mathrm{C}$ for $1 \mathrm{~h}$. For each experiment, serial dilutions of labelled PBMC were made to allow linear regression of the number of cells adherent to the endothelial cells for a particular experiment. A separate regression analysis was performed for each experiment to eliminate variability due to differences in calcein AM labelling. After incubation, the plate was washed three times with PBS. Then, fluorescence, representing adherent PBMC, was recorded at a wavelength of $\mathrm{Ex} / \mathrm{Em}=485 / 525 \mathrm{~nm}$ with a fluorescence microplate reader (FLUOstar OPTIMA, BMG Labtech, Ortenberg, Germany). Each test was performed with six replicate wells and each plate was inspected with an inverted light microscope to ensure that the endothelial layers remained intact during the course of the experiments.

\section{Drugs and materials}

The following compounds were purchased from SigmaAldrich: HSA, minimally gHSA $(2.2 \mathrm{~mol}$ hexose $/ \mathrm{mol}$ protein), cytochrome $\mathrm{C}$ and $\beta-\mathrm{NADH}$. All of the reagents were diluted directly in PBS before the experiments. Collagenase IA from Gibco (Invitrogen) was prepared in PBS pH 7.5-22 U/ml. The specific materials used on each technique are indicated in the appropriate sections.

Published by Bioscientifica Ltd. 
The Slide-A-Lyzer dialysis cassettes (10 000 molecular weight cutoff) were from Pierce. All aqueous solutions were prepared using water from a nanopure water system and filtered using $0.22 \mu \mathrm{m}$ nylon filters from Fisher (Pittsburgh, PA, USA). All of the other compounds for the experimental solutions were of the maximal molecular grade.

\section{Data analysis}

Data are expressed as mean \pm s.E.M. ROS production was expressed as the ratio for treatment/control experiments. The mRNA and protein levels of VCAM-1 and ICAM-1 were expressed as the fold change of each treatment with respect to control treatment. The percentage of PBMC adhesion was calculated based on the mean fluorescence (MF) seen in treatments to the MF seen in controls. Twogroup comparisons were performed by the two-tailed Student's $t$-test. Multiple comparisons were evaluated by ANOVA followed by Tukey's test. Statistical significance was considered when $P<0.05$.

\section{Results}

\section{Characterization of the glycation products}

The presence of ESGP and ASGP in commercial minimally glycated albumin (gHSA) and human serum albumin, incubated with glucose in the lab for 4 weeks (AGE-HSA), was analysed using MALDI-TOF-MS. As we can see in Fig. 1A, analysis of HSA gave rise to three unique peaks.
The main peak at $66478 \mathrm{Da}$ is the monocharged ion of HSA. There are two smaller peaks, one at $33240 \mathrm{Da}$ and another at $22154 \mathrm{Da}$, which correspond to double- and triple-charged ions of HSA respectively (Fig. 1A). The analysis by MALDI-TOF-MS of the glycated proteins showed a clear increase over the molecular weight of HSA, caused by the glycation process. In the case of the gHSA, the main peak was slightly higher than HSA, with a mass difference of about $173 \mathrm{Da}$ (Fig. 1B). For the AGE-HSA, the shifted mass was much bigger, and a more heterogeneous product with a mass difference at a maximum of 2504 Da was obtained (Fig. 1C). These differences in mass showed in the MALDI-TOF-MS spectra are caused by multiple glycation modifications and can be used to estimate the average glycation rate of the protein. Considering the incorporation of one hexose as an increase of $162 \mathrm{Da}$ in the total molecular weight, gHSA presented 1.1 of glycation rate in front of 15.4 for AGE-HSA.

To corroborate these results, free amino groups were measured by TNBSA assay in gHSA and AGE-HSA in relation with their controls HSA and ct-HSA respectively. Results showed a $60.4 \% \pm 2.4 \%$ of free amino groups for AGE-HSA with respect to ct-HSA and a $69.0 \% \pm 1.9 \%$ for gHSA in relation with HSA.

\section{Peptide mapping of the glycation products}

To further characterize the modifications present in these proteins, we analysed gHSA and AGE-HSA tryptic peptides
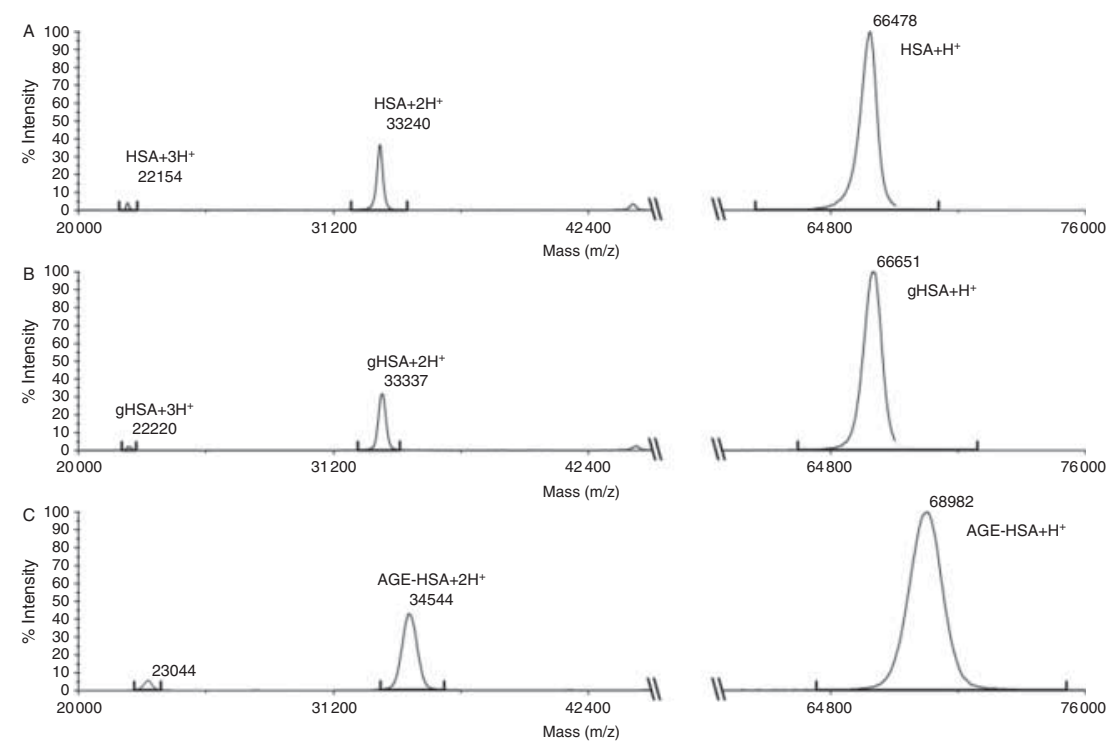

Figure 1

Analysis by MALDI-TOF-MS of HSA (A), gHSA (B) and AGE-HSA (C) plotted mass-to-charge ratio $(\mathrm{m} / \mathrm{z})$ vs the percentage intensity. A mass shift between different HSA glycation stages is observed in comparison with HSA. 
by MALDI-TOF-MS. By comparing both spectra, the presence of glycation adducts on both glycated albumins was identified after determining the tryptic peptide ions with mass values, which were only present in the glycated samples. Then, modifications present in these peptides were characterized by comparing the mass shift with a list of shift mass deviations caused by different glycation adducts (see Supplementary Table S2, see section on supplementary data given at the end of this article). By using this approach, several ESGP and ASGP were assigned and identified in the glycated samples (Tables 1 and 2). Two restrictions were used on this process to facilitate the assignment of the modifications: only a single modification was allowed within a fragment and the peptide must contain a missed cleavage site (lysine/arginine). Normally, after glycation modification, lysine or arginine residues become resistant to trypsin cleavage, resulting in a missed cleaved peptide (Zhang et al. 2003). However, we also found several peptides with a modification, but without a missed cleavage site, they were not included in the analysis (see Supplementary Tables S3 and S4).

Following these criteria, 11 glycomodified peptides were identified from a total of 31 tryptic peptides of gHSA that cover $25.98 \%$ of the HSA amino acid sequence and represent $43.68 \%$ of the sequence identified (Table 1 and Supplementary Table S5, see section on supplementary data given at the end of this article). In these peptides, 16 different modifications were characterized, five of which were ESGP and the other 11 were ASGP. Residues K73, K159, K378 and K402 were modified with ESGP, whereas residues R117, K136, R145, K372, K402, K414 and
R445 presented ASGP such as Ne-carboxyethyl-lysine (CEL), pyrraline, Ne-(5-Hydro-5-methyl-4-imidazolon2-yl)ornithine (MG-H1), Ne-(5-Hydro-4-imidazolon-2-yl) ornithine (GH-1), 1-Alkyl-2-formyl-3,4-glycosyl-pyrrole (AFGP) or pentosidine/ Ne-carboxymethyl-lysine (CML).

The tryptic digestion of AGE-HSA allowed the identification of 16 glycomodified peptides of a total of 30 peptides identified that cover $39.49 \%$ of the AGE-HSA amino acid sequence and representing $63.81 \%$ of the sequence identified (Table 2 and Supplementary Table S6, see section on supplementary data given at the end of this article). In these 16 peptides, 27 different modifications were characterized, 11 or 12 of which were ESGP and 15 or 16 were ASGP. The ESGP were found in residues R117, K323, K414, K519 and in residues K4, K12, K137, K159, K212, K233, K378, K402, which also presented ASGP. The types of ASGP modifications found were almost the same than in gHSA. Nevertheless, crossline was also detected, and it was not found in the gHSA. Neither carboxyethyllysine nor hydro-imidazolon-ornithine (GH-1) were found, although they were present in gHSA. Only eight of the modified peptides appeared in both gHSA and AGEHSA (sequence positions: 94-106, 115-136, 115-137, 146$160,373-389,414-428,445-466$ and 501-521). Interestingly, most of the times the modifications found were not the same. In some cases they passed from an ESGP to an ASGP, as in residues K159 and K378. However, the rest of the modified residues were different for the two modified albumins (see Tables 1 and 2).

Therefore, the glycation patterns for gHSA and AGEHSA were slightly different in terms of type and number of

Table 1 Glycation-modified peptides identified on gHSA by MALDI-TOF-MS peptide mapping

\begin{tabular}{|c|c|c|c|c|c|}
\hline $\begin{array}{l}\text { Position of } \\
\text { sequence }\end{array}$ & $\begin{array}{l}\text { Modified } \\
\text { residue }\end{array}$ & Peptide sequence & Detected m/z & Observed $\Delta \mathrm{m}(\mathrm{Da})$ & Modification type \\
\hline $65-81$ & K73 & SLHTLFGDKLCTVATLR & 2094.10 & +162.02 & $\mathrm{FL}$ \\
\hline 94-106 & R98 & QEPERNECFLQHK & 1768.91 & +54.01 & MG-H1 \\
\hline \multirow[t]{2}{*}{$115-136$} & $\mathrm{R} 117$ & LVRPEVDDMCTAFHDNEETFLK & 2704.30 & +54.01 & MG-H1 \\
\hline & R117 & & 2792.36 & +142.03 & Imadazolone B \\
\hline $115-137$ & R117, K136 & LVㅁPEVDVMCTAFHDNEETFLㅌK & 2940.39 & $\begin{array}{c}+162.03 \\
(108.02+54.01)\end{array}$ & MG-H1 and Pyrraline \\
\hline $145-159$ & R145 & RHPYFYAPELLFFAK & 1938.96 & +39.9 & $\mathrm{GH}-1$ \\
\hline $146-160$ & K159 & ḦPYFYAPELLFFAKR & 2061.05 & +162.02 & $\mathrm{FL}$ \\
\hline \multirow[t]{3}{*}{ 198-205 } & K199 & LKCASLQK - & 1055.57 & +108.02 & Pyrraline \\
\hline & K199 & & 1089.58 & +142.03 & $\mathrm{FL}-1 \mathrm{H}_{2} \mathrm{O}$ \\
\hline & K199 & & 1217.66 & +270.07 & AFGP \\
\hline $373-389$ & K378 & VFDEFK & 2207.13 & +162.02 & $\mathrm{FL}$ \\
\hline \multirow[t]{2}{*}{$414-428$} & K414 & KVPQV̄STPTLVEVSR & 1697.78 & +58.02 & Pentosidine/CML \\
\hline & K414 & & 1711.81 & +72.02 & CEL \\
\hline $445-466$ & R445 & RMPCAEDYLSVVLNQLCVLHEK & 2816.32 & +142.03 & Imadazolone B \\
\hline $501-521$ & K519 & $\bar{E} F N A E T F T F H A D I C T L S E \underline{K} E R$ & 2707.23 & +162.02 & $\mathrm{FL}$ \\
\hline
\end{tabular}

AFGP, 1-alkyl-2-formyl-3,4-glycosyl-pyrrole; CEL, NE-carboxyethyl-lysine; CML, Ne-carboxymethyl-lysine; FL, fructosyl-lysine; GH-1, Ne-(5-hydro-4-imidazolon2-yl)ornithine; MG-H1, Ne-(5-hydro-5-methyl-4-imidazolon-2-yl)ornithine. 
Table 2 Glycation-modified peptides identified on AGE-HSA by MALDI-TOF-MS peptide mapping

\begin{tabular}{|c|c|}
\hline $\begin{array}{l}\text { Position of } \\
\text { sequence }\end{array}$ & Modified residue \\
\hline $1-10$ & $\begin{array}{l}\mathrm{N} \text {-terminal or } \mathrm{K} 4 \\
\mathrm{~N} \text {-terminal or } \mathrm{K} 4 \\
\mathrm{~N} \text {-terminal or } \mathrm{K} 4\end{array}$ \\
\hline $11-20$ & $\begin{array}{l}\mathrm{K} 12 \\
\mathrm{~K} 12 \\
\mathrm{~K} 12\end{array}$ \\
\hline $94-106$ & R98 \\
\hline $115-136$ & R117 \\
\hline $115-137$ & $\begin{array}{l}\text { R117 or } \mathrm{K} 136 \\
\mathrm{R} 117 \text { and } \mathrm{K} 136\end{array}$ \\
\hline $137-144$ & $\begin{array}{l}\text { K137 } \\
\text { K137 }\end{array}$ \\
\hline $146-160$ & $\begin{array}{l}\text { K159 } \\
\text { K159 }\end{array}$ \\
\hline $210-218$ & $\begin{array}{l}\text { K212 } \\
\text { K212 }\end{array}$ \\
\hline $226-240$ & $\begin{array}{l}\mathrm{K} 233 \\
\mathrm{~K} 233\end{array}$ \\
\hline $318-336$ & K323 \\
\hline $338-351$ & R348 \\
\hline $373-389$ & $\begin{array}{l}\text { K378 } \\
\text { K378 }\end{array}$ \\
\hline $390-410$ & $\begin{array}{l}\mathrm{K} 402 \\
\mathrm{~K} 402\end{array}$ \\
\hline $414-428$ & K414 \\
\hline $445-466$ & R445 \\
\hline $501-521$ & K519 \\
\hline
\end{tabular}

\begin{tabular}{|c|}
\hline Peptide sequence \\
\hline DAHKSEVAHR (N-terminal or $\mathrm{K}$ \\
\hline FKEDLGEENFK \\
\hline $\begin{array}{l}\text { QEPERNECFLQHK } \\
\text { LVRPEVDVMCTAFHDNEETFLK } \\
\text { LV } \underline{R} \text { PEVDVMCTAFHDNEETFLKK }\end{array}$ \\
\hline$\underline{\text { KYYYEIAR }}$ \\
\hline HPYFYAPELLFFAKR \\
\hline AFK彑AWAVAR \\
\hline AEFAEVSKLLVTDLTK \\
\hline $\begin{array}{l}\text { NYAEAKDVFLGMFLYEYAR } \\
\text { HPDYSVVLLLRLAK } \\
\text { VFDEFKYPLVEEPQN̄LIK }\end{array}$ \\
\hline QNC*ELFEQLGEYKGFQNALLVR \\
\hline $\begin{array}{l}\text { KVPQVSTPTLVEVSR } \\
{ }^{\star} \text { RMPC*AE- } \\
\text { DVYLSVVLNQLC*VLHEK } \\
\text { EFNAETFTFHADIC*TLSEKER }\end{array}$ \\
\hline
\end{tabular}

\begin{tabular}{c}
$\begin{array}{c}\text { Detected } \\
\mathbf{m} / \mathbf{z}\end{array}$ \\
\hline 1207.62 \\
1311.64 \\
1419.68 \\
1388.71 \\
1478.80 \\
1496.67 \\
1984.87 \\
2792.31 \\
2922.41 \\
2940.40 \\
1217.64 \\
1163.61 \\
1957.07 \\
2061.02 \\
1077.62 \\
1181.66 \\
1759.93 \\
1813.92 \\
2462.20 \\
1681.93 \\
2207.22 \\
2297.21 \\
2657.41 \\
2761.45 \\
1802.05 \\
2818.45 \\
\\
2707.32 \\
\hline
\end{tabular}

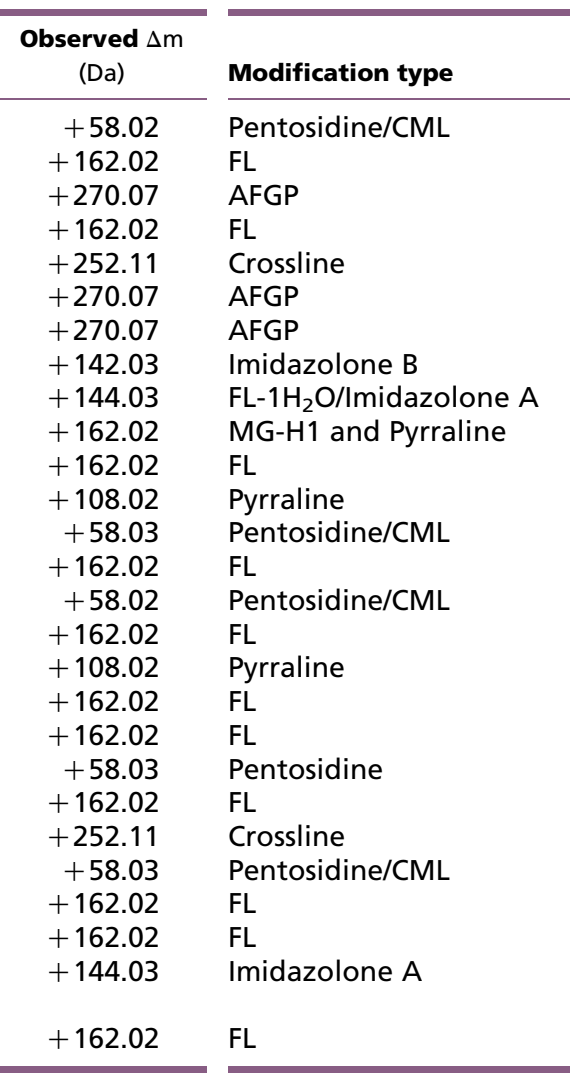

AFGP, 1-alkyl-2-formyl-3,4-glycosyl-pyrrole; CML, Ne-carboxymethyl-lysine; FL, fructosyl-lysine; MG-H1, Ne-(5-hydro-5-methyl-4-imidazolon-2-yl)ornithine

modifications, and AGE-HSA presented more ASGP than gHSA, although this type of modifications also appears in the low glycated protein.

\section{Cell viability}

A Real-Time Cell Analyzer (RTCA) was used to monitor dynamic changes in the viability of HUVEC cells under different concentrations of gHSA or AGE-HSA $(12-400 \mu \mathrm{g} / \mathrm{ml})$ and their respective controls with HSA or ct-HSA respectively. Control experiments were also carried out to test the possible cytotoxicity of any of the above treatments. CI values were normalized to 1.000 a.u. at the moment of the treatment and followed throughout the experiments. These CI grew linearly in all of the cases showing no detectable toxic effects over the cells. Therefore, CI values at $12 \mathrm{~h}$ of treatment were considered to check the cell's viability in comparison with control experiments. Results are shown in Supplementary Table S7, see section on supplementary data given at the end of this article. There were no statistical differences between the treatments (gHSA, AGE-HSA, HSA or ct-HSA) and the cells with any treatment. Furthermore, there were no differences either between gHSA or AGE-HSA and their respective HSA and ct-HSA at any concentration. These results suggested that under the conditions of our experiments no cytotoxic effects on HUVEC were found.

\section{ROS production}

Once the different composition in glycation products of both types of molecules was characterized, we proceeded to investigate the differential effects produced by both gHSA and AGE-HSA. As we previously reported (RodinoJaneiro et al. 2010), treatment with gHSA $(25-100 \mu \mathrm{g} / \mathrm{ml})$ for different times (4-12 h) induced significant increments of ROS production with respect to the same concentration of HSA (used as control). The maximal response was obtained with $25 \mu \mathrm{g} / \mathrm{ml}$ gHSA and after $4 \mathrm{~h}$ of treatment $(1.14 \pm 0.04$ for the ratio gHSA/HSA, $P<0.05$ with respect to HSA, $n=10$; Fig. 2A). With this treatment some effects at $6 \mathrm{~h}$ or even at $12 \mathrm{~h}$ can still be detected, but they are not

Published by Bioscientifica Ltd. 

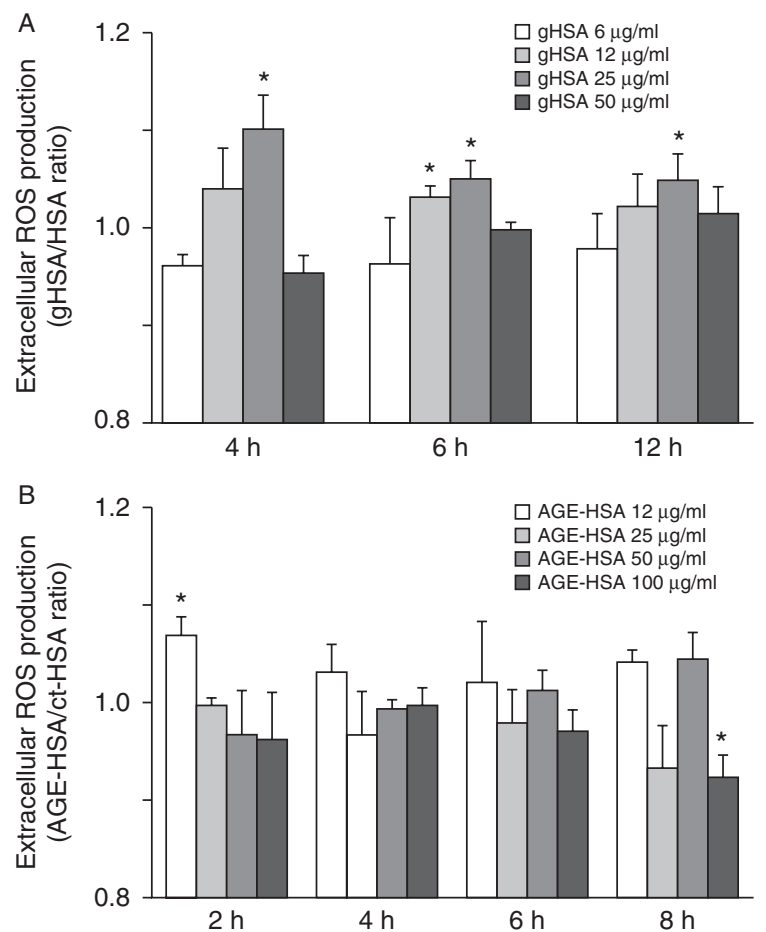

Figure 2

Extracellular reactive oxygen species (ROS) production in HUVEC after treatment with different concentrations of (A) $\mathrm{gHSA}(6-50 \mu \mathrm{g} / \mathrm{ml})$ or (B) AGE-HSA $(12-100 \mu \mathrm{g} / \mathrm{ml})$, for periods of time indicated on each graph. HUVEC were serum and supplements starved for $12 \mathrm{~h}$ prior to the treatments. Columns represent the ratio of ROS produced by treatment/ control molecules expressed as mean \pm S.E.M. (vertical bars) of at least three independent experiments. $P<0.05$ with respect to the control values.

significant. According to that, we chose the concentration of $25 \mu \mathrm{g} / \mathrm{ml}$ of gHSA for the following experiments.

Then, we studied the effects of AGE-HSA, a different glycation product, under the same conditions. An anticipation of the effects was observed, because AGEHSA increased ROS production at lower concentrations and shorter times than gHSA $(1.07 \pm 0.04$ with $12 \mu \mathrm{g} / \mathrm{ml}$ for the ratio AGE-HSA/ ct-HSA for $2 \mathrm{~h}$ ). However, at long incubation periods, the ROS-inducing effects of gHSA were maintained, whereas no significant increases on ROS production were observed with AGE-HSA at $4-8 \mathrm{~h}$ (Fig. 2B). Interestingly, high concentrations of AGE-HSA $(100 \mu \mathrm{g} / \mathrm{ml})$ after $8 \mathrm{~h}$ of treatment significantly reduced ROS production in comparison with the same concentration of ct-HSA $(0.92 \pm 0.05$ for the ratio AGE-HSA/ ct-HSA, $P<0.05, n=5$; Fig. $2 \mathrm{~B}$ ).

Intracellular ROS production is shown in Table 3. It was measured by cDCF-DA after $4 \mathrm{~h}$ (the same time used for the functional experiments) of treatment with gHSA or AGE-HSA $(12-100 \mu \mathrm{g} / \mathrm{ml})$ and expressed in relation to their controls HSA and ct-HSA, respectively. Interestingly, at $25 \mu \mathrm{g} / \mathrm{ml}$, gHSA significantly enhanced intracellular ROS production $(1.19 \pm 0.09 ; P<0.05)$, whereas AGE-HSA only showed a trend to slightly increase it $(1.06 \pm 0.04$; $P=0.056$ ). On the contrary, at $100 \mu \mathrm{g} / \mathrm{ml}$ AGE-HSA significantly reduced intracellular ROS production $(0.86 \pm 0.06 ; P<0.05)$, whereas gHSA showed a trend to increase it $(1.10 \pm 0.10 ; P=0.081)$.

Therefore, differences in the induction of ROS production were observed between gHSA (a low glycated product) and AGE-HSA (a high glycated product).

\section{Adhesion molecules expression}

The mRNA expression of VCAM-1 and ICAM-1 was evaluated by RT-qPCR. Melting temperatures were checked for every qPCR product in all of the reactions and were always as follows: $80^{\circ} \mathrm{C}$ (product of $207 \mathrm{bp}$ ) for VCAM- $1 ; 86^{\circ} \mathrm{C}$ (259 bp) for ICAM-1 and $88^{\circ} \mathrm{C}$ (149 bp) for $\beta$-actin. As maximum increase in ROS production was obtained at a concentration of $25 \mu \mathrm{g} / \mathrm{ml}$ of gHSA, the effects of this concentration on VCAM-1 and ICAM-1 expression were analysed (Fig. $3 \mathrm{~A}$ and $\mathrm{B}$ ). At this concentration, gHSA produced significant increases in VCAM-1 and ICAM-1 mRNA expression levels after $4 \mathrm{~h}$ of incubation $(1.34 \pm 0.20$ and $1.32 \pm 0.06$ fold changes for VCAM-1 and ICAM-1, respectively; $P<0.05$ with respect to HSA). These increases in mRNA levels were transient, because they were not observed after 6 or $8 \mathrm{~h}$ of incubation (Fig. $3 \mathrm{~A}$ and $\mathrm{B}$ ), indicating a relatively quick and temporary activation of HUVEC by gHSA.

Table 3 Intracellular ROS production in HUVEC after $4 \mathrm{~h}$ of treatment with different concentrations of gHSA and AGE-HSA. Results are shown as the ratio treatment/respective control, expressed as mean \pm s.E.M. of at least four independent experiments. Comparisons were made between each treatment and its respective control and the $P$ values for the Student's $t$-tests are shown

\begin{tabular}{|c|c|c|}
\hline Treatments & $\begin{array}{c}\text { Intracellular ROS } \\
\text { production } \\
\text { (Modified-HSA/ } \\
\text { Control-HSA) }\end{array}$ & $\begin{array}{c}\text { Student's } t \text {-test } \\
\text { (P value) }\end{array}$ \\
\hline $\mathrm{gHSA} 12 \mu \mathrm{g} / \mathrm{ml}$ & $1.09 \pm 0.06$ & 0.126 \\
\hline AGE-HSA $12 \mu \mathrm{g} / \mathrm{ml}$ & $1.42 \pm 0.36$ & 0.116 \\
\hline $\mathrm{gHSA} 25 \mu \mathrm{g} / \mathrm{ml}$ & $1.19 \pm 0.09$ & 0.009 \\
\hline AGE-HSA $25 \mu \mathrm{g} / \mathrm{ml}$ & $1.06 \pm 0.04$ & 0.056 \\
\hline $\mathrm{gHSA} 50 \mu \mathrm{g} / \mathrm{ml}$ & $1.04 \pm 0.05$ & 0.351 \\
\hline AGE-HSA $50 \mu \mathrm{g} / \mathrm{ml}$ & $1.04 \pm 0.03$ & 0.136 \\
\hline $\mathrm{gHSA} 100 \mu \mathrm{g} / \mathrm{ml}$ & $1.10 \pm 0.10$ & 0.081 \\
\hline AGE-HSA $100 \mu \mathrm{g} / \mathrm{ml}$ & $0.86 \pm 0.06$ & 0.013 \\
\hline
\end{tabular}

Published by Bioscientifica Ltd. 

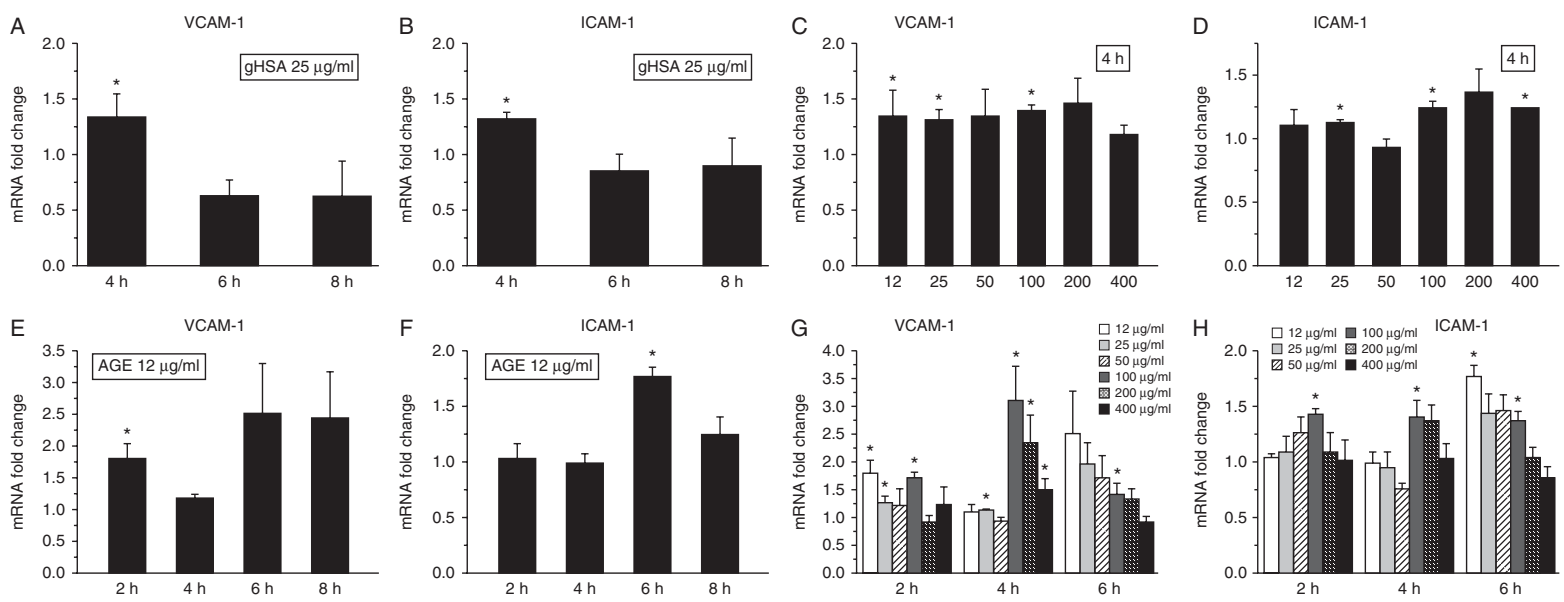

\section{Figure 3}

Expression levels of mRNA for VCAM-1 (A, C, E and G) and for ICAM-1 (B, D, $\mathrm{F}$ and $\mathrm{H}$ ) after the treatment with $\mathrm{gHSA} 12-400 \mu \mathrm{g} / \mathrm{ml}(\mathrm{A}, \mathrm{B}, \mathrm{C}$ and $\mathrm{D})$ or AGEHSA $12-400 \mu \mathrm{g} / \mathrm{ml}(\mathrm{E}, \mathrm{F}, \mathrm{G}$ and $\mathrm{H})$ during the periods and concentrations indicated on each graph. Columns represent the fold change of mRNA

As gHSA seems to have an effect on VCAM-1 and ICAM- 1 only after $4 \mathrm{~h}$ of treatment, we investigated the variations on the expression of these adhesion molecules using different concentrations of gHSA $(12-400 \mu \mathrm{g} / \mathrm{ml})$ within this time (Fig. 3C and D). The maximum significative effect of gHSA for both adhesion molecules was observed at $100 \mu \mathrm{g} / \mathrm{ml}(1.38 \pm 0.05$ and $1.23 \pm 0.04$ fold changes for VCAM-1 and ICAM-1, respectively; $P<0.05$ with respect to controls).

In a similar way, we analysed the effect of $12 \mu \mathrm{g} / \mathrm{ml}$ of AGE-HSA at different times (2, 4, 6 and $8 \mathrm{~h})$. As shown in Fig. 3E, there was only a significant increase in VCAM-1 expression after $2 \mathrm{~h}(1.79 \pm 0.46$ fold changes; $P<0.05)$. However, after longer treatment periods there seemed to be a trend to an increase in VCAM- 1 expression, as we can see with a $6 \mathrm{~h}$ exposition. Nevertheless, this increase was not significant $(P=0.079)$. The expression profile of ICAM-1 with $12 \mu \mathrm{g} / \mathrm{ml}$ AGE-HSA was quite different (Fig. 3F), and we only detected a significant up-regulation at $6 \mathrm{~h}(1.75 \pm 0.09$ fold change; $P<0.05)$.

Due to the differences shown in the mRNA expression of both types of adhesion molecules, dose- (12-400 $\mu \mathrm{g} / \mathrm{ml})$ and time-dependent (2-6h) response curves were performed with AGE-HSA treatment (Fig. $3 G$ and $\mathrm{H}$ ). AGE-HSA increased mRNA levels for both VCAM-1 and ICAM-1 in HUVEC, although with different patterns of cell activation as compared to gHSA. Indeed, high concentrations of AGE-HSA $(100 \mu \mathrm{g} / \mathrm{ml})$ induced significant increases in the mRNA levels for both adhesion molecules after 2, 4 and $6 \mathrm{~h}$ of incubation (Fig. 3G and $\mathrm{H}$ ), but not at

expression for each gene, expressed as mean values \pm s.E.M. (vertical bars) of at least three independent experiments. ${ }^{*} P<0.05$ with respect to the values for unmodified human serum albumin.

longer times ( 8 and $12 \mathrm{~h}$; data not shown). VCAM-1 expression was also induced at lower concentrations $(25 \mu \mathrm{g} / \mathrm{ml})$ at 2 and $4 \mathrm{~h}$ of incubation. Higher concentrations than $100 \mu \mathrm{g} / \mathrm{ml} \mathrm{had}$ no effect on ICAM-1 expression. However, in VCAM- 1 after $4 \mathrm{~h}$ of treatment, some effects were observed $(2.33 \pm 0.50$ and $1.48 \pm 0.21$ fold changes for 200 and $400 \mu \mathrm{g} / \mathrm{ml}$ AGE-HSA respectively; $P<0.05$ with respect to ct-HSA).

In summary, AGE-HSA up-regulated ICAM-1 and VCAM- 1 expression more than gHSA, in terms of mRNA fold changes. Even while the effects of gHSA seemed to be limited to $4 \mathrm{~h}$ of treatment, AGE-HSA up-regulate VCAM-1 and ICAM-1 expression for longer periods of time (from 2 to $6 \mathrm{~h}$ ). Differences on the active concentrations of both glycation products were also observed: whereas gHSA was only active at $25 \mu \mathrm{g} / \mathrm{ml}$, AGE-HSA was also effective at 12 and $100 \mu \mathrm{g} / \mathrm{ml}$.

Protein levels of VCAM-1 and ICAM-1 were analysed by western blot of whole cell extracts from HUVEC, which have been treated during $4 \mathrm{~h}$ with 25 or $100 \mu \mathrm{g} / \mathrm{ml}$ gHSA, AGEHSA or their specific controls HSA or ct-HSA, respectively. Although moderate, there was an elevation of VCAM- 1 and ICAM-1 levels caused by the effect of both AGE-HSA concentrations. On the other hand, only the concentration of $25 \mu \mathrm{g} / \mathrm{ml}$ gHSA enhanced ICAM-1 protein levels (Fig. 4). TNF- $\alpha(10 \mathrm{ng} / \mathrm{ml})$ was used in these experiments as a positive control for VCAM-1 and ICAM-1 up-regulation.

\section{PBMC adhesion}

The possible functional translation of VCAM-1 and ICAM-1 up-regulation was analysed by the adhesion of PBMC to

Published by Bioscientifica Ltd 


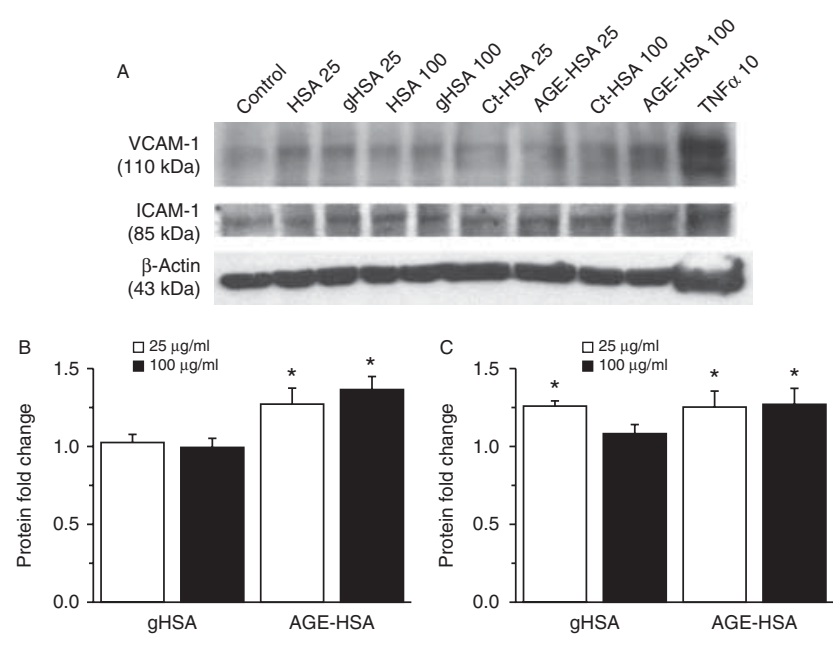

Figure 4

Expression levels of VCAM-1 and ICAM-1 measured by western blot in HUVEC protein extracts obtained after $4 \mathrm{~h}$ of treatment with gHSA or AGEHSA ( 25 or $100 \mu \mathrm{g} / \mathrm{ml}$, as indicated). TNF- $\alpha(10 \mathrm{ng} / \mathrm{ml})$ was used as a positive inducer drug. (A) Representative blots for VCAM-1, ICAM-1 and $\beta$-actin. Columns represent the fold change of protein expression for (B) VCAM-1 and (C) ICAM-1 calculated by optical densitometry with respect to $\beta$-actin and expressed as mean values \pm s.E.M. (vertical bars) of at least three independent experiments. ${ }^{\star} P<0.05$ with respect to unmodified human serum albumin.

HUVEC monolayers after treatment with both types of modified albumins for $4 \mathrm{~h}$.

In these conditions, gHSA $(25 \mu \mathrm{g} / \mathrm{ml})$ induced no significant effect in PBMC adhesion in comparison with HSA $(10.7 \pm 0.3 \%$ vs $10.3 \pm 0.4 \%$ for gHSA and HSA respectively). However, the AGE-modified molecules induced a significant increase in the adhesion of PBMC to HUVEC monolayers. In comparison with ct-HSA, AGEHSA $(25 \mu \mathrm{g} / \mathrm{ml})$ significantly enhanced PBMC adhesion $(11.5 \pm 0.6 \%$ vs $11.0 \pm 0.6 \%$ for AGE-HSA and ct-HSA respectively; $P<0.05)$. Other AGE-modified molecules used as AGE standard, CML $(25 \mu \mathrm{g} / \mathrm{ml})$, also increased cell adhesion to HUVEC in relation to the treatment with HSA $(11.4 \pm 0.4 \%$ vs $10.3 \pm 0.4 \%$ for CML and HSA respectively; $P<0.05$; Fig. 5$)$. TNF- $\alpha(10 \mathrm{ng} / \mathrm{ml})$ was used in these experiments as positive controls because it induces endothelial cell activation and promotes PBMC adhesion to the endothelial monolayer (Fig. 5).

\section{Discussion}

This is the first work that directly compares the effects of two different well-characterised stages of glycated albumin on the functionality of human endothelial cells. Whereas gHSA, a low glycated protein, enhanced ROS production permanently in HUVEC at low concentrations, the high glycated protein, AGE-HSA, caused a temporary anticipation of the induced ROS production. This was observed even at lower concentrations than for gHSA. Although gHSA up-regulated the gene expression of adhesion molecules in HUVEC, it seems that this up-regulation was not enough to enhance the adhesion of mononuclear cells to HUVEC monolayers at the functional level. Only AGE-HSA, which also up-regulated adhesion molecules at mRNA and protein levels in HUVEC, functionally enhanced the adhesion of PBMC to endothelial monolayers. These data support the hypothesis that low and high glycated proteins produce different pathophysiological effects on endothelial cells, which could also have a different translation to the clinical vascular complications.

Despite the fact that the relevance of non-enzymatic glycation of proteins has been widely proved by clinical evidences in different pathological conditions as diabetes mellitus, renal failure and degenerative diseases, this type of post-translational modification is one of the less studied (Priego Capote \& Sanchez 2009). However, the glycation process is of high interest because tridimensional structure, biological function and turnover of proteins are altered by this process (Ulrich \& Cerami 2001). Having this in mind, the objective of this work was first to elucidate the composition in different glycation products of two different glycated molecules (gHSA, an example of low glycated protein, and AGE-HSA, an example of high glycated protein), to further analyse the different effects of both types of molecules in several measures of endothelial functionality.

HSA is the most abundant protein in serum. This protein is a long-lived protein (21 days), which contains 585 amino acids residues with 83 potential modification sites (59 lysines, 24 arginines and the $N$-terminal amine). All of these characteristics facilitate the formation and accumulation of glycated modifications and AGE adducts on it, making it a suit model of the glycation process. This protein is involved in a large amount of functions in the whole body and its glycation can lead to alterations in the active sites, deeply impairing its functions. HSA from healthy donors has a molecular weight between 66572 and $66694 \mathrm{Da}$ and from diabetic patients between 66785 and $68959 \mathrm{Da}$ (Lapolla et al. 1995). In our study, commercial HSA without any modification provides a main peak at $66478 \mathrm{Da}$, a little bit lower than the range for healthy people. In the minimally glycated commercial gHSA, the peak was slightly higher than HSA (66 $651 \mathrm{Da}$ ), ranging into the levels of healthy subjects, suggesting that healthy people already present a certain amount of glycation on their proteins. In the case of the AGE-HSA

Published by Bioscientifica Ltd. 
A
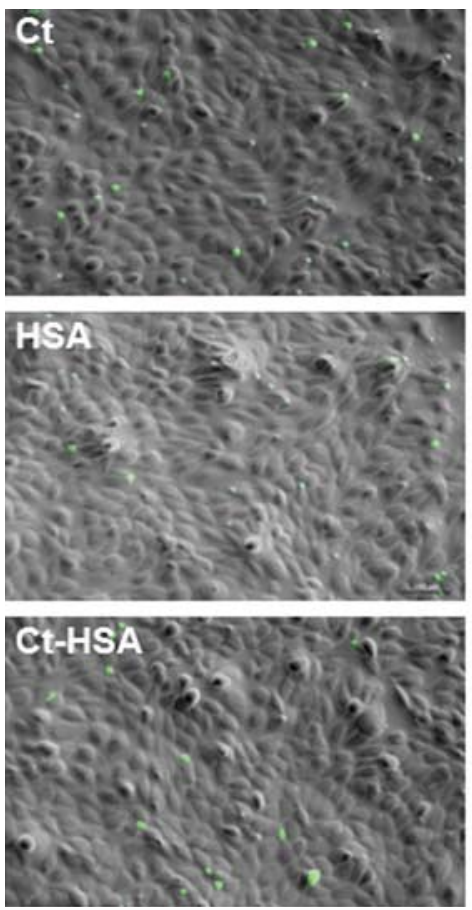
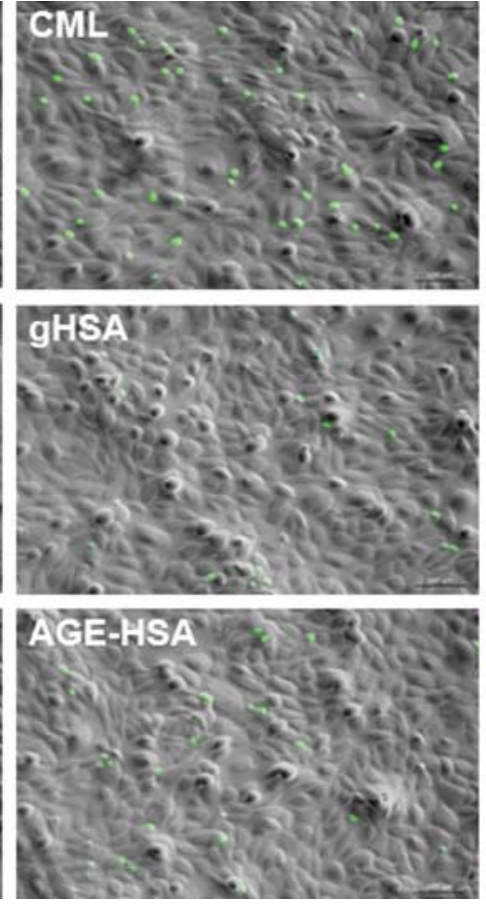

B
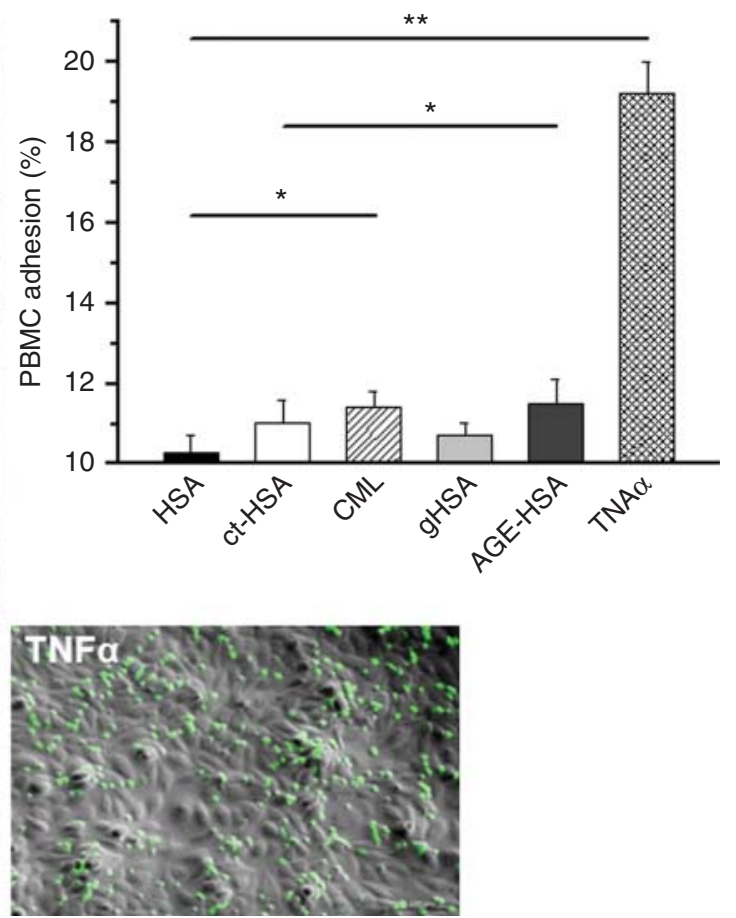

Figure 5

Representative merged images of PBMC stained with calcein AM over a transmitted image of an HUVEC monolayer. HUVEC were treated during $4 \mathrm{~h}$ with $\mathrm{gHSA}(25 \mu \mathrm{g} / \mathrm{ml})$, AGE-HSA $(25 \mu \mathrm{g} / \mathrm{ml})$ or $\mathrm{CML}(25 \mu \mathrm{g} / \mathrm{ml})$ and compared with HSA $(25 \mu \mathrm{g} / \mathrm{ml})$, ct-HSA $(25 \mu \mathrm{g} / \mathrm{ml})$ or control (no treatment),

prepared in the lab, the mass shift was higher with a maximum at $68982 \mathrm{Da}$, being even a little bit higher than the upper limit for the people with poorly controlled diabetes. As a consequence, an AGE-HSA sample could represent the highest level of glycation in vivo, as it might occur in advanced and uncontrolled diabetes.

The first studies on protein glycation were developed for quantification of the glycation level in specific proteins (Peterson et al. 1998, Zhang et al. 2001). This estimation is based on the $162 \mathrm{Da}$ mass shifts experienced for the condensation of one glucose molecule on the protein per glycation site, allowing the calculus of the average number of glucose molecules attached to a protein. Accordingly, the increase in mass on gHSA and AGE-HSA should correspond with the condensation of 1.1 and 15.4 glucose units per molecule of albumin respectively, and they correlate with the average degree of glycation. However, these units of glucose represent the minimum number of glucose molecules present on the protein, as the condensed molecules can undergo further oxidation and dehydration reactions leading to species of lower molecular weight (Lapolla et al. 2013). The quantification of free amino respectively. TNF- $\alpha(10 \mathrm{ng} / \mathrm{ml})$ was used as a positive control for the assay. The graph represents the mean percentage of adhesion (columns) \pm s.E.M. (vertical bars) of at least three independent experiments. ${ }^{\star} P<0.05$; $\star * P<0.01$.

groups in both glycated proteins also confirmed a higher occupation of amino residues in AGE-HSA than in gHSA.

MS offers the potential advantage of providing both structural and qualitative information to clarify the regions that are being modified during the glycation process along with the form of these modifications (Cravatt et al. 2007). Specifically, the MALDI-TOF-MS technique offers an overview of the total protein modifications independent of their structure and chemical and physical properties (Kislinger et al. 2005). Peptide mapping has been introduced into the analysis of AGE-modified proteins by MALDI-TOF-MS, allowing site-specific analysis of defined ESGP and ASGP (Kislinger et al. 2005). This approach has two major advantages over the analysis of intact proteins. First, the generated peptides usually have a molecular mass between 500 and $5000 \mathrm{Da}$, therefore allowing isotopic resolution by MALDI-TOF-MS to identify specific ESGP and ASGP structures. Second, the assignment of a modification to defined peptides can lead to a sitespecific analysis of glycated products (Kislinger et al. 2005).

A couple of restrictions were employed to facilitate the analysis (Zhang et al. 2003), as explained in the 'Results'

Published by Bioscientifica Ltd 
section. However, although they were not included in the analysis, we observed several peptides with a modification but without a missed cleavage site. So it may happen that the modifications do not affect trypsin digestion in particular cases.

The type of modifications found are known and previously described, as shown in Supplementary Table S2, see section on supplementary data given at the end of this article. The glycation patterns for gHSA and AGE-HSA were slightly different. AGE-HSA presented more glycomodified peptides and residues than gHSA. Even the percentage of the glycated sequence was higher in the case of AGE-HSA. It also showed a greater number of different modifications for both early and advanced glycation stages in comparison with gHSA. Glycomodifications were not found always in the same residues for both molecules. Furthermore, when they were, modifications present were not always the same, and sometimes they turned from an ESGP in gHSA to an ASGP in AGEHSA. As compared to gHSA, AGE-HSA did not present CEL or GH-1 modifications but did crossline. Regarding the residues modified in both products, all have been always previously reported by others except for R348 and R445 (for a revision, see Anguizola et al. 2013). However, some of the most reported glycomodified residues, for example, K525, K439, K199, K51 or R128, were not found for our conditions. This difference in the glycomodified residues is quite frequent and dependent on the in vitro or in vivo origin of the glycated sample and the conditions of the reaction regarding time, concentration of sugar and temperature (Anguizola et al. 2013). Moreover, the coverage of our modified albumins is not complete and this could be one of the causes of the absence of these modifications. Furthermore, the presence of several misscleaved in a specific region can affect the detection of these specific modifications.

Modifications on HSA by Maillard reaction led to the induction of ROS by endothelial cells not only by ASGP but also by ESGP, as shown by our results. Interestingly, in our experimental conditions gHSA induced ROS production at extra- and intracellular levels in HUVEC at low concentrations and after $4 \mathrm{~h}$ of treatment, as previously shown (Rodino-Janeiro et al. 2010). However, AGE-HSA was able to increase extracellular ROS production at lower concentrations and shorter times of treatment than gHSA but only showed a trend to increase intracellular ROS at $25 \mu \mathrm{g} / \mathrm{ml}$ and $4 \mathrm{~h}$ of treatment. These results suggest that the accumulation of glycated modifications on HSA induce pro-oxidant effects on endothelial cells and that progression from ESGP to ASGP can enhance this effect. Clearly, this could have a direct impact on mechanisms of diabetic vascular complications. In the case of AGE-HSA, higher concentrations $(100 \mu \mathrm{g} / \mathrm{ml})$ reduced intracellular ROS, whereas in the case of gHSA, there seems to be only a trend to increase it, yet showing another difference between low and high glycated proteins.

The pro-oxidant effects shown by gHSA and AGE-HSA would be added to the impairment of the natural antioxidant properties of native albumin, to which glycation contribute, as shown previously by Baraka-Vidot et al. (2013). Furthermore, ROS production would in turn activate the redox-sensitive transcription nuclear factor $\mathrm{NF}-\kappa \mathrm{B}$, a pleiotropic regulator of many inflammatory genes including cell adhesion molecules. Therefore, our data corroborate that such activation could be done by ESGP and ASGP, because both modifications enhanced ROS production in endothelial cells. Even more, this could be done independently from RAGE activation, as ESGP seemed not to act through this receptor (Zhang et al. 2006).

Under the same conditions, ROS production induced by gHSA or AGE-HSA in HUVEC is followed by an up-regulated expression of two different adhesion molecules such as VCAM-1 and ICAM-1. However, in this case, the functional translation of this observation was different for low and high glycated proteins. Only the high glycated protein and ASGP (AGE-HSA and CML respectively) were able to significantly increase the adhesion of PBMC to HUVEC monolayers in vitro. It seems that the gHSA-induced up-regulation of adhesion molecules at mRNA levels was not always followed by an increase of protein levels, so that is not the only requirement to enhance the adhesion of mononuclear cells. If confirmed in vivo, this point is clinically crucial because it means that only high glycation or ASGP modifications, but not low glycation levels, can enhance the adhesion of inflammatory cells to the endothelial lumen. In other words, controlling the level of HSA glycation in diabetic patients could serve to prevent cell adhesion to the vessel wall.

AGE-induced VCAM-1 up-regulation has been previously reported in endothelial cell monolayers and this has been related to enhanced T-lymphoblast cell adhesion to endothelial cells (Schmidt et al. 1995). Not only VCAM1 but also ICAM-1 and E-selectin enhanced expression has been observed after AGE treatment on human endothelial cells (Kunt et al. 1998). Even more, AGE activate the function of cell adhesion molecules on lymphoid cells (Kyurkchiev et al. 1997). A focal enhanced VCAM-1 and

Published by Bioscientifica Ltd. 
ICAM-1 expression in the endothelium of rabbits treated chronically with AGE has also been shown (Vlassara et al. 1995), suggesting an ongoing endothelial activation, an early feature of arterial lesion formation. Time variation of VCAM-1 and ICAM-1 expression is not surprising because they are inducible molecules in endothelial cells (Kim et al. 2001). In this sense, maximum expression after $4 \mathrm{~h}$ of stimulus, as observed with gHSA, is quite frequent. It is more intriguing the relation of gHSA- and AGE-HSAinduced up-regulations with their doses. Apparently, lower concentrations of both molecules are better stimuli than higher concentrations, although this is more pronounced for gHSA than for AGE-HSA. This behaviour could be related to effects non-mediated by RAGE, as occurs in the case of gHSA (Zhang et al. 2006).

Our experiments also revealed that VCAM-1 and ICAM-1 up-regulation could not be enough to enhance mononuclear phagocytes adhesion to endothelial cells monolayers, because gHSA induced up-regulation of these adhesion molecules. This was confirmed at the protein level at least for ICAM-1, without a functional increase in cell adhesion. It could indicate that other concomitant mechanisms are needed to finally promote the binding of mononuclear phagocytes to the endothelial surface. Importantly, in the case of non-enzymatic glycation, these mechanisms would be activated by high, but not by low, glycated proteins.

One possible explanation for these results is the involvement of RAGE activation on the effects of glycated products. Low glycated proteins would not act through this receptor (Zhang et al. 2006), whereas the effects of high glycated proteins with more ASGP are partially dependent on RAGE. This fact allows the possibility of low expression of RAGE under certain conditions and even the expression of truncated and dysfunctional variants of this receptor. These situations could explain the lack of response to AGE stimulation by endothelial cells in particular cases (Lieuw-a-Fa et al. 2006).

In conclusion, our data suggest interesting and functional differences between low and high glycated proteins. gHSA enhanced more stable ROS production over time in HUVEC at low concentrations, whereas AGEHSA at lower concentrations than gHSA caused a temporary anticipation on the induced extracellular ROS production. Although both gHSA and AGE-HSA up-regulated the expression of VCAM-1 and ICAM-1 in HUVEC at mRNA level, only AGE-HSA increased also the protein levels of both adhesion molecules and enhanced the adhesion of peripheral blood mononuclear cells to endothelial cells monolayers at a functional level.
Consequently, these observations support the hypothesis that low and high glycated proteins with different content in ESGP and ASGP produce different pathophysiological effects on endothelial cells. Therefore, they could have important clinical repercussions on the atherogenesis process or in the development of vascular complications associated with diabetes.

\section{Supplementary data}

This is linked to the online version of the paper at http://dx.doi.org/10.1530/ JME-15-0031.

\section{Declaration of interest}

The authors declare that there is no conflict of interest that could be perceived as prejudicing the impartiality of the research reported.

\section{Funding}

This study was partially supported by grants from the Spanish Society of Cardiology (2014) and the Plan Estatal de Investigación Científica y Técnica y de Innovación 2013-2016, and the Instituto de Salud Carlos III (grant number PI14/01140), co-financed by European Regional Development Fund. The work of Beatriz Paradela-Dobarro was supported by Instituto de Salud Carlos III (grant number Fl11/00325).

\section{Acknowledgements}

CML-HSA was kindly provided by Dr Ann Marie Schmidt from New York University Langone Medical Center. Thanks to Centro de Transfusiones de Galicia (Santiago de Compostela, Spain) for providing buffy coats.

\section{References}

Anguizola J, Matsuda R, Barnaby OS, Hoy KS, Wa C, DeBolt E, Koke M \& Hage DS 2013 Review: glycation of human serum albumin. Clinica Chimica Acta 425 64-76. (doi:10.1016/j.cca.2013.07.013)

Baraka-Vidot J, Guerin-Dubourg A, Dubois F, Payet B, Bourdon E \& Rondeau P 2013 New insights into deleterious impacts of in vivo glycation on albumin antioxidant activities. Biochimica et Biophysica Acta 1830 3532-3541. (doi:10.1016/j.bbagen.2013.01.019)

Bucala R, Makita Z, Koschinsky T, Cerami A \& Vlassara H 1993 Lipid advanced glycosylation: pathway for lipid oxidation in vivo. PNAS 90 6434-6438. (doi:10.1073/pnas.90.14.6434)

Cravatt BF, Simon GM \& Yates JR III 2007 The biological impact of mass-spectrometry-based proteomics. Nature 450 991-1000. (doi:10.1038/nature06525)

Fandino-Vaquero R, Fernandez-Trasancos A, Alvarez E, Ahmad S, Batista-Oliveira AL, Adrio B, Fernandez AL, Gonzalez-Juanatey JR \& Eiras S 2014 Orosomucoid secretion levels by epicardial adipose tissue as possible indicator of endothelial dysfunction in diabetes mellitus or inflammation in coronary artery disease. Atherosclerosis 235 281-288. (doi:10.1016/j.atherosclerosis.2014.05.921)

Funk SD, Yurdagul A Jr \& Orr AW 2012 Hyperglycemia and endothelial dysfunction in atherosclerosis: lessons from type 1 diabetes. International Journal of Vascular Medicine 2012569654. (doi:10.1155/2012/569654) 
Kim I, Moon SO, Kim SH, Kim HJ, Koh YS \& Koh GY 2001 Vascular endothelial growth factor expression of intercellular adhesion molecule 1 (ICAM-1), vascular cell adhesion molecule 1 (VCAM-1), and E-selectin through nuclear factor- $\mathrm{B}$ activation in endothelial cells. Journal of Biological Chemistry 276 7614-7620. (doi:10.1074/jbc. M009705200)

Kislinger T, Humeny A, Peich CC, Becker CM \& Pischetsrieder M 2005 Analysis of protein glycation products by MALDI-TOF/MS. Annals of the New York Academy of Sciences 1043 249-259. (doi:10.1196/annals. 1333.030)

Kunt T, Forst T, Harzer O, Buchert G, Pfutzner A, Lobig M, Zschabitz A, Stofft E, Engelbach M \& Beyer J 1998 The influence of advanced glycation endproducts (AGE) on the expression of human endothelial adhesion molecules. Experimental and Clinical Endocrinology \& Diabetes 106 183-188. (doi:10.1055/s-0029-1211974)

Kyurkchiev S, Ivanov G \& Manolova V 1997 Advanced glycosylated end products activate the functions of cell adhesion molecules on lymphoid cells. Cellular and Molecular Life Sciences 53 911-916. (doi:10.1007/ s000180050110)

Lapolla A, Fedele D, Seraglia R, Catinella S, Baldo L, Aronica R \& Traldi P 1995 A new effective method for the evaluation of glycated intact plasma proteins in diabetic subjects. Diabetologia 38 1076-1081. (doi:10.1007/BF00402178)

Lapolla A, Molin L \& Traldi P 2013 Protein glycation in diabetes as determined by mass spectrometry. International Journal of Endocrinology 2013 412103. (doi:10.1155/2013/412103)

Lieuw-a-Fa ML, Schalkwijk CG, Engelse M \& van Hinsbergh VW 2006 Interaction of Nepsilon(carboxymethyl)lysine- and methylglyoxalmodified albumin with endothelial cells and macrophages. Splice variants of RAGE may limit the responsiveness of human endothelial cells to AGEs. Thrombosis and Haemostasis 95 320-328. (doi:10.1267/ THRO06020320)

Luevano-Contreras C \& Chapman-Novakofski K 2010 Dietary advanced glycation end products and aging. Nutrients 2 1247-1265. (doi:10.3390/ nu2121247)

Maillard LC 1912 The action of amino acids on sugar; the formation of melanoidin by a methodic route. Comptes Rendus Hebdomadaires Des Séances De L'Académie Des Sciences 154 66-68.

Negre-Salvayre A, Coatrieux C, Ingueneau C \& Salvayre R 2008 Advanced lipid peroxidation end products in oxidative damage to proteins. Potential role in diseases and therapeutic prospects for the inhibitors. British Journal of Pharmacology 153 6-20. (doi:10.1038/sj.bjp.0707395)

Ott C, Jacobs K, Haucke E, Navarrete Santos A, Grune T \& Simm A 2014 Role of advanced glycation end products in cellular signaling. Redox Biology 2 411-429. (doi:10.1016/j.redox.2013.12.016)

Peterson KP, Pavlovich JG, Goldstein D, Little R, England J \& Peterson CM 1998 What is hemoglobin A1c? An analysis of glycated hemoglobins by electrospray ionization mass spectrometry Clinical Chemistry $\mathbf{4 4}$ 1951-1958.

Prasad K 2014 Low levels of serum soluble receptors for advanced glycation end products, biomarkers for disease state: myth or reality. International Journal of Angiology 23 11-16. (doi:10.1055/s-0033-1363423)
Priego Capote F \& Sanchez JC 2009 Strategies for proteomic analysis of non-enzymatically glycated proteins. Mass Spectrometry Reviews $\mathbf{2 8}$ 135-146. (doi:10.1002/mas.20187)

Rahman K 2007 Studies on free radicals, antioxidants, and co-factors. Clinical Interventions in Aging 2 219-236.

Rodino-Janeiro BK, Gonzalez-Peteiro M, Ucieda-Somoza R, GonzalezJuanatey JR \& Alvarez E 2010 Glycated albumin, a precursor of advanced glycation end-products, up-regulates NADPH oxidase and enhances oxidative stress in human endothelial cells: molecular correlate of diabetic vasculopathy. Diabetes/Metabolism Research and Reviews 26 550-558. (doi:10.1002/dmrr.1117)

Schmidt AM, Hori O, Chen JX, Li JF, Crandall J, Zhang J, Cao R, Yan SD, Brett J \& Stern D 1995 Advanced glycation endproducts interacting with their endothelial receptor induce expression of vascular cell adhesion molecule-1 (VCAM-1) in cultured human endothelial cells and in mice. A potential mechanism for the accelerated vasculopathy of diabetes. Journal of Clinical Investigation 96 1395-1403. (doi:10.1172/ JCI118175)

Sims TJ, Rasmussen LM, Oxlund H \& Bailey AJ 1996 The role of glycation cross-links in diabetic vascular stiffening. Diabetologia 39 946-951. (doi:10.1007/BF00403914)

Thorpe SR \& Baynes JW 2003 Maillard reaction products in tissue proteins: new products and new perspectives. Amino Acids 25 275-281. (doi:10.1007/s00726-003-0017-9)

Ulrich P \& Cerami A 2001 Protein glycation, diabetes, and aging. Recent Progress in Hormone Research 56 1-21. (doi:10.1210/rp.56.1.1)

Vlassara H, Fuh H, Donnelly T \& Cybulsky M 1995 Advanced glycation endproducts promote adhesion molecule (VCAM-1, ICAM-1) expression and atheroma formation in normal rabbits. Molecular Medicine 1 447-456.

Zhang M, Kho AL, Anilkumar N, Chibber R, Pagano PJ, Shah AM \& Cave AC 2006 Glycated proteins stimulate reactive oxygen species production in cardiac myocytes: involvement of Nox2 (gp91phox)-containing NADPH oxidase. Circulation 113 1235-1243. (doi:10.1161/CIRCULATIONAHA.105.581397)

Zhang Q, Ames JM, Smith RD, Baynes JW \& Metz TO 2009 A perspective on the Maillard reaction and the analysis of protein glycation by mass spectrometry: probing the pathogenesis of chronic disease. Journal of Proteome Research 8 754-769. (doi:10.1021/pr800858h)

Zhang X, Medzihradszky KF, Cunningham J, Lee PD, Rognerud CL, Ou CN, Harmatz P \& Witkowska HE 2001 Characterization of glycated hemoglobin in diabetic patients: usefulness of electrospray mass spectrometry in monitoring the extent and distribution of glycation. Journal of Chromatography. B, Biomedical Sciences and Applications 759 1-15. (doi:10.1016/S0378-4347(01)00196-7)

Zhang Y, Cocklin RR, Bidasee KR \& Wang M 2003 Rapid determination of advanced glycation end products of proteins using MALDI-TOF-MS and PERL script peptide searching algorithm. Journal of Biomolecular Techniques 14 224-230.

Zieman SJ \& Kass DA 2004 Advanced glycation endproduct crosslinking in the cardiovascular system: potential therapeutic target for cardiovascular disease. Drugs 64 459-470. (doi:10.2165/00003495-200464 050-00001)

Received in final form 23 September 2015

Accepted 8 October 2015 http://jme.endocrinology-journals.org

DOI: 10.1530/JME-15-0031
() 2016 Society for Endocrinology Printed in Great Britain
Published by Bioscientifica Ltd. 